\title{
BERISLAM DALAM BINGKAI INDONESIA: MEMBACA KONSEP PLURALISME ABDURRAHMAN WAHID
}

Oleh: Miftahuddin ${ }^{1}$

\begin{abstract}
Abstrak
Sebuah kenyataan historis bahwa Indonesia adalah bangsa yang majemuk, plural, dan beragam. Setelah Indonesia ini lahir, masyarakat bangsa ini semestinya menyadari bahwa mereka adalah tidak satu, banyak suku, banyak agama, dan banyak latar belakang budaya yang berbeda. Demikian pula seiring dengan perkembangan zaman dan di era globalisasi ini, jelas keragaman semakin tampak. Masyarakat Indonesia, pada era ini, tidak hanya harus bisa bergaul dengan sesama bangsa Indonesia, akan tetapi juga harus dapat menerima bangsa lain sekaligus pengaruh budayanya. Dalam konteks ini, penting kiranya untuk mengkaji pemikiran Gus Dus, sebutan akrab Abdurrahman Wahid. Diketahui bahwa Gus Dur salah satu intelektual yang banyak menyuarakan gagasangagasan pluralism baik dalam tulisan-tulisannya maupun tindakan nyata. Oleh karena itu, artikel ini bertujuan mengungkap pemikiran Gus Dur. Khususnya, bagaimana seharusnya ber-Islam dalam bingkai Indonesia dalam pandangan Gus Dur?
\end{abstract}

Kata Kunci: ber-Islam, pemikiran Gus Dur, dan pluralisme

\section{A. Pendahuluan}

Sudah tidak asing lagi dalam telinga masyarakat Indonesia, sebagaimana dikatakan Barton, bahwa salah satu aspek yang paling bisa dipahami dari Gus Dur, panggilan akrab Abdurrahman Wahid, adalah penyeru pluralisme dan toleransi, sekaligus dalam realita kehidupannya, dia adalah pembela kelompok minoritas. Dengan kata lain, Abdurrahman Wahid dipahami sebagai muslim nonchauvinis, sebagai figura yang memperjuangkan diterimanya kenyataan sosial bahwa Indonesia itu beragam. Gus Dur adalah orang yang bangga sebagai seorang muslim, sekaligus dia sangat mencintai kebudayaan Islam tradisional, dan pesan utama Islam-lah yang dipraktikkan Gus Dur dalam kehidupan beragama. ${ }^{2}$ Bagaimana pandangan pluralisme Gus Dur, terutama dikaitkan dengan ber-Islam di Indonesia?

\footnotetext{
${ }^{1}$ Staf Pengajar Jurusan Pendidikan Sejarah FIS UNY

${ }^{2}$ Greg Barton, "Memahami Abdurrahman Wahid", dalam Abdurrahman Wahid, Prisma Pemikiran Gus Dur, (Yogyakarta: LKiS, 2010), hlm. xxiii.
} 
Sebelum membaca lebih jauh konsep pluralisme Gus Dur, tampaknya lebih tepat untuk mengungkap arti pluralisme itu sendiri. Pluralisme berasal dari akar kata Latin, plus, pluris, yang secara harfiah berarti: lebih dari satu. Dalam pengertian filosofisnya, pluralisme adalah paham atau ajaran yang mengacu kepada adanya kenyataan yang lebih dari satu (individu). Dengan demikian, secara mendasar pemutlakan tidaklah tepat, baik dalam pemikiran maupun dalam sikap, sehingga senantiasa harus disadari bahwa tidak mungkin kenyataan yang mahakaya ini direduksi hanya menjadi satu-satunya kenyataan. Setiap individu misalnya mempunyai keunikan, baik dalam cara berpikir, berpersepsi, maupun bertindak, sehingga memutlakkan merupakan suatu pemerkosaan terhadap (hakhak) individu yang bersangkutan. ${ }^{3}$

Sementara itu, An-Na'im dalam menjelaskan arti pluralisme disandingkan dengan arti keragaman. Keragaman (diversity) adalah perbedaan dalam persoalan agama, etnik, dan data demografis lainnya, sedangkan pluralisme (pluralism) adalah sistem nilai, sikap, institsi, dan proses yang bisa menterjemahkan realitas keragaman itu menjadi kohesi sosial yang berkelanjutan, stabilitas politik, dan pembangunan ekonomi. Dengan kata lain, keragaman adalah sesuatu yang empiris, sedangkan pluralisme adalah ideologi atau orientasi dan sistem yang menerima keragaman itu sebagai nilai yang positif dan terus berusaha memfasilitasi proses negosiasi dan penyesuaian di antara mereka, tanpa berusaha memusnahkan salah satu atau sebagian dari keragaman itu. Misalnya, adanya perbedaan dalam persoalan agama dan kepercayaan adalah ciri utama setiap masyarakat, dan pluralisme adalah orientasi atau sistem yang mengasumsikan adanya penerimaan yang tulus atas fakta empiris tersebut dengan cara mengatur hubungan di antara komunitas agama yang berbeda, dan bukan berusaha meleburnya menjadi satu atau memusnahkan salah satunya. ${ }^{4}$

${ }^{3}$ Andreas A. Yewangoe, "Regulasi Toleransi dan Pluralisme Agama di Indonesia”, http://abad demokrasi.com/sites/default/files/ebook/Merayakan \%20Kebebasan\%20 Beragama\%20DP.pdf, diakses tanggal 6 Maret 2012.

4 Abdullahi Ahmed An-Na'im, Islam dan Negara Sekuler: Menegosiasikan Masa Depan Syariah, terj. Sri Murniati, (Bandung: Mizan, 2007), hlm. 391-392. 


\section{B. Geneologi Intelektual Abdurrahman Wahid}

Abdurrahman Wahid yang sering disebut dengan Gus Dur lahir pada tanggal 7 September 1940. Ayah Gus Dur adalah Kiai Wahid Hasyim, putra Kiai Hasyim Asy’ari, dan ibunya Solichah, putra Kiai Bisri Syansuri. Sejak kecil Gus Dur dididik dan dibesarkan dalam keluarga pesantren dan di bawah naungan keluarga ulama. Sejak usia 5 tahun Gus Dur sudah lancar membaca, dan dalam pertumbuhannya dia adalah sebagai seorang pecandu bacaan. Gus Dur memulai pendidikan dasarnya di SD KRIS di Jakarta Pusat. Ia mengikuti pelajaran di kelas tiga dan kemudian di kelas empat. Akan tetapi dia kemudian pendah ke SD Matraman Pertiwi, yang terletak di dekat rumah keluarga yang baru di Matraman, Jakarta Pusat. Jelas pada tahap ini, pendidikan Gus Dur sepenuhnya bersifat sekuler. Namun, tentu saja ia telah mempelajari Bahasa Arab ketika kecil dan mempunyai cukup pengetahuan untuk dapat membaca Al-Qur'an. ${ }^{5}$

Pada tahun 1955 Gus Dur melanjutkan ke SMEP (Sekolah Menengah Ekonomi Pertama) Gowangan, Yogyakarta, sambil belajar di Pesantren Krapyak. Di pesantren ini, kegemaran Gus Dur terhadap buku semakin meningkat. Oleh karena kemampuannya dalam menguasai Inggris, ketika usia 15 tahun, dia sudah menguasai Das Kapital-nya Karl Marx, filsafat Plato, Thalles, novel-novel William Bochner, dan buku-buku lain yang dipinjamkan gurunya di SMEP. Setelah tamat dari SMEP, dia melanjutkan belajar di Pesantren Tegalrejo, Magelang. Sekitar tiga tahun di pesantren ini, dia merasa bahwa pendalamannya terhadap ilmu agama masih belum cukup sehingga kembali ke Jombang belajar di Pesantren Denanyar, yang diasuh kakeknya Bisri Syansuri. ${ }^{6}$

Pada tahun 1960-an, ketika berusia 23 tahun, dia memperoleh kesempatan belajar ke Mesir melalui beasiswa Departemen Agama. Ketika itu, dia telah menyelesaikan gramatka bahasa Arab seribu bait yang sudah dihafal di luar kepala. Di negeri ini, dia mengambil spesialisasi bidang syariah, namun setelah

${ }^{5}$ Greg Barton, Biografi Gus Dur, terj. Lie Hua, (Yogyakarta: LKiS, 2010), hlm. 26-47.

${ }^{6}$ Mujamil Qomar, NU Liberal: Dari Tradisionalisme Ahlusunnah ke Universalisme Islam, (Bandung: Mizan, 2002), hlm. 166. 
tujuh tahun, dia merasa tidak kerasan karena menurutnya tidak lebih dari pesantren. Oleh karena itu, dia lebih memilih aktif di organisasi Perhimpunan Mahasiswa Indonesia dari pada menekuni belajar. Akhirnya, dia pindah ke Irak untuk mengikuti kuliah di Universitas Baghdad, fakultas sastra. Di tempat inilah bakat empirisnya dapat tumbuh dengan pesat. Dia banyak membaca karya-karya, seperti pemikiran Emile Durkeim. ${ }^{7}$

\section{Islam Rahmatan Lil 'Alamin: Tafsir Atas Pancasila}

Pertama yang perlu ditegaskan, bahwa Indonesia adalah salah satu bangsa paling plural di dunia. Dengan 17 ribu pulau yang ada di wilayahnya, baik besar maupun kecil, baik dihuni maupun tidak. Indonesia adalah negara kepulauan terbesar di dunia, dan negara dengan latar belakang paling beragam. Dengan sekitar 400 kelompok etnis dan bahasa yang ada di bawah naungannya, Indonesia juga adalah sebuah negara dengan kebudayaan sangat beragam ${ }^{8}$, termasuk agama. Keanekaragaman (pluralitas) agama yang hidup di Indonesia, termasuk di dalamnya keanekaragaman paham keagamaan yang ada di dalam tubuh intern umat beragama adalah merupakan kenyataan historis yang tidak bisa disangkal oleh siapa pun. Sementara itu, proses munculnya pluralitas agama di Indonesia dapat diamati secara empiris historis. ${ }^{9}$

Dalam kondisi yang plural ini, maka ketika Islam mau berperan dalam segala aspek kehidupan di Indonesia, yang tepat adalah peran substantif, yaitu mengembangkan pesan-pesan moral dengan tema-tema sentral, seperti keadilan dan egalitarianisme, bukan hanya menonjolkan simbol. ${ }^{10}$ Pandangan semacam inilah yang sering dikemukakan Gus Dur. Oleh karena itu, dalam banyak hal, yang diperjuangkan Gus Dur adalah bagaimana memunculkan Islam dalam bentuk

\section{${ }^{7}$ Ibid.}

${ }^{8}$ Ali Maschan Moesa, NU Agama dan Demokrasi:Komitmen Muslim Tradisional Terhadap Nilai-Nilai Kebangsaan, (Surabaya: Putra Pelajar, 2002), hlm. 159.

${ }^{9}$ M. Amin Abdullah, Studi Agama: Normativitas atau Historisitas?, (Yogyakarta: Pustaka Pelajar, 2002), hlm. 5

${ }^{10}$ Aden Wijdan SZ. dkk, Pemikiran dan Peradaban Islam, (Yogyakarta: Safiria Insania Press), hlm. 136. 
esensi ajaran-ajarannya bukan dari bentuknya. Gus Dur, misalnya, lebih memprioritaskan permasalahan sosial dan ekonomi ketimbang masalah kekuatan politik dari suatu organisasi umat. Nilai-nilai etik dan kerja semestinya lebih diutamakan ketimbang mempermasalahkan apakah seorang Muslimah harus mengenakan jilbab atau tidak. ${ }^{11}$

Hal demikian tampak ketika Gus Dur melihat peran yang substantif dalam Islam. Jadi, menurut Gus Dur ada dua kategori manusia: pertama, orangorang yang sudah mampu menjinakkan hawa nafsu sehingga bisa memberi manfaat kepada siapa pun. Mereka adalah pribadi-pribadi yang tenang dan damai (an-nafs al-muthmainnah) dan menjadi representasi kehidupan spiritual, khalifah Allah yang sebenarnya. Kedua, mereka yang masih dikuasai hawa nafsu sehingga selalu menjadi biang keresahan dan masalah bagi siapa pun. Mereka adalah pribadi-pribadi gelisah dan menjadi biang kegelisahan sosial dan pembuat masalah (al-nafs al-lawwamah) dan menjadi representasi kehadiran hawa nafsu. ${ }^{12}$

Pertentangan antara jiwa-jiwa yang tenang dengan jiwa-jiwa yang resah ini mewarnai sejarah semua penjuru dunia. Akan tetapi, di Nusantara, sekalipun pertentangan selalu terjadi berulang-ulang sejak nenak moyang bangsa Indonesia, ajaran spiritual dan nilai-nilai luhur jiwa-jiwa yang tenang tetap dominan. Prinsip “Bhineka Tunggal Ika” Mpu Tantular, misalnya, telah mengilhami para penguasa Nusantara dari jaman Hindu-Budha hingga dewasa ini. Demikian pula, Sunan Kalijaga, yang terkenal akomodatif terhadap tradisi lokal, mendidik para penguasa pribumi tentang Islam yang damai, toleran, dan spiritual. Pada masa Indonesia modern, dapat disaksikan kehadiran jiwa-jiwa yang tenang ini, antara lain dalam proses kelahiran dan tumbuhnya kesadaran kebangsaan, khususnya dalam dialog antara Islam dan nasionalisme Indonesia. Para ulama, seperti Abikusno Tjokrosujoso, KH. A. Kahar Muzakkir, H. Agus Salim, KH. A. Wahid Hasyim,

${ }^{11}$ Saiful Muzani, "Mitos Politik dan Aspirasi Politik ICMI Modernis”, Book Review, Adam Schwarz, "Islam: Coming in from the Cold?, dalam bukunya, A Nation in Waiting, Indonesia in the 1990's, (Sydney: Allan and Unwin, 1994), Studia Islamika, Volume 2, Number 1, 1995, hlm. 223.

${ }^{12}$ Abdurrahman Wahid, "Musuh dalam Selimut”, Pengantar Editor, dalam Abdurrahman Wahid (ed.), Ilusi Negara Islam: Ekspansi Gerakan Islam Transnasional di Indonesia, (Jakarta: Desantra Utama Media, 2009), hlm. 15. 
Ki Bagus Hadikusumo, Kasman Singodimejo, Teuku Mohammad Hasan, dan tokoh-tokoh penting pendiri bangsa lainnya, sadar bahwa negara yang akan mereka perjuangkan dan pertahankan bukanlah negara yang didasarkan pada dan untuk agama tertentu, melainkan negara bangsa yang mengakui dan melindungi segenap agama, beragam budaya dan tradisi yang telah menjadi bagian integral kehidupan bangsa Indonesia. ${ }^{13}$ Oleh karena itu, munculnya Pancasila sebagai dasar negara Indonesia adalah bagian dari ini.

Para pendiri bangsa Indonesia sadar bahwa di dalam Pancasila tidak ada prinsip yang bertentangan dengan ajaran agama. Sebaliknya, prinsip-prinsip dalam Pancasila justru merefleksikan pesan-pesan utama semua agama, yang dalam ajaran Islam dikenal sebagai maqashid al-syari'ah, yaitu kemaslahatan umum. Dengan kesadaran demikian mereka menolak pendirian atau formalisasi agama dan menekankan substansinya. Mereka memposisikan negara sebagai institusi yang mengakui keragaman, mengayomi semua kepentingan, dan melindungi segenap keyakinan, budaya, dan tradisi bangsa Indonesia. Dengan demikian, melalui Pancasila mereka menghadirkan agama sebagai wujud kasih sayang Tuhan bagi seluruh makhluk-Nya (rahmatan lil'alamin) dalam arti sebenarnya. Sikap para tokoh nasionalis religius yang berjuang mempertahankan bangunan kebangsaan NKRI berdasarkan Pancasila dan UUD 1945 ini, menurut Gus Dur, dapat disebut sebagai kehadiran jiwa-jiwa yang tenang (al-nafs almuthmainnah), pribadi-pribadi yang terus berusaha untuk memberi manfaat sebanyak mungkin kepada siapa pun tanpa mempermasalahan perbedaanperbedaan yang ada. ${ }^{14}$

Lebih lanjut dikatakan, bahwa dalam pandangan fiqh, asas Pancasil adalah salah satu dari sekian buah persyaratan bagi keabsahan negara Republik Indonesia, dan bukannya persyaratan keagamaan sama sekali. Oleh karena itu, dengan sendirinya tidak ada alasan apa pun untuk menolaknya, selama ia tidak berfungsi menggantikan kedudukan agama dalam kehidupan organisasi yang bersangkutan. Islam sendiri dapat saja diletakkan dalam kedudukan yang berbeda

\footnotetext{
${ }^{13}$ Ibid., hlm. 16-17.

${ }^{14}$ Ibid., hlm. 18.
} 
dalam kehidupan organisasi, dalam kurun waktu yang berlainan. Pada suatu saat ia dijadikan asas, di waktu lain dijadikan landasan keimanan (aqidah), karena masalahnya "hanyalah sekedar pencapaian legitimasi” dalam pandangan fiqh. ${ }^{15}$

Dalam hal ini, Gus Dur menyetir gagasan Asghar Ali Engineer bahwa sebenarnya berdirinya negara Islam sudah memenuhi gagasan negara modern yang bersifat sekuler. Ada persamaan tujuan antara negara sekuler dan negara Islam, yaitu sama-sama melindungi hak-hak pribadi para warga negaranya. Apabila jalan pikiran ini diikuti dengan konsekuen, maka yang menjadi ukuran satu-satunya baik negara Islam maupun sekuler adalah kesejaheraan warga negara secara perorangan, dan selebihnya hanyalah bentuk luar yang dapat saja diubah oleh rakyat melalui lembaga perwakilan mereka. Dengan demikian, sebenarnya negara Indonesia yang berdasarkan Pancasila sudah satu tujuan dengan negara Islam. $^{16}$

Demikian pula, Azyumardi Azra mengatakan, bahwa puncak dari pengembangan “teologi kerukunan” Islam di Indonesia, tentu saja, adalah penerimaan Pancasila sebagai dasar negara dan ideologi nasional pada 18 Agustus 1945. Dalam konteks hubungan antar agama di Indonesia, Pancasila dapat dikatakan merupakan perwujudan dari panggilan mengembangkan kalîmatun sawâ. Dari proses penerimaan Pancasila itu, jelas terlihat bahwa para pemimpin Islam lebih mementingkan kerukunan dan integrasi nasional daripada mendahulukan kepentingan Islam dan umat muslim belaka. Dalam perspektif mayoritas muslim Indonesia, penerimaan Pancasila merupakan hadiah terbesar umat Islam bagi kesatuan dan keutuhan bangsa dan negara Indonesia yang majemuk dari segi agama, suku bangsa, adat istiadat, dan lain-lain. ${ }^{17}$

\footnotetext{
${ }^{15}$ Abdurrahman Wahid, "Nahdatul Ulama dan Islam di Indonesia dewasa Ini”, dalam Taufif Abdullah dan Sharon Siddique, Tradisi dan Kebangkitan Islam di Indonesia, (Jakarta: LP3ES, 1988), hlm. 201

${ }^{16}$ Abdurrahman Wahid, "Bercermin Dari Para Pemimpin”, dalam Abdul Mu'nim D.Z. (ed.), Islam di Tengah Arus Transisi, (Jakarta: Kompas, 2000), hlm. 287

17 Azyumardi Azra, “Toreransi Agama dalam Masyarakat Majemuk: Perspektif Muslim Indonesia”, http://abad-demokrasi.com/sites/default/
} 
Sejalan dengan apa yang ditegaskan Nurcholish Madjid, dengan menyetir pandangannya Mohammad Hatta, bahwa sebuah negara atau negara yang secara resmi berlandaskan agama tidaklah perlu didirikan. Sebenarnya, masalah yang terpenting adalah substansinya, yaitu keadilan, yang harus diperjuangkan untuk dilaksanakan oleh sebuah negara. Orang-orang Muslim, tanpa perlu menanamkan negara mereka sebagai “Negara Islam (Indonesia)”, mungkin akan mendapat basis etis substansi ini dalam ajaran Islam. Menurut Nurcholish, kini bangsa Indonesia sangat comfortable dengan gagasan mereka berkenaan dengan hubungan antara agama dan negara, yang didasarkan pada Pancasila sebagai titik temu antara seluruh golongan. ${ }^{18}$

\section{Aktualisasi Pluralisme}

Sikap yang hanya mau menggunakan kata "syaikh”, serban, dan jubah sebagai ilustrasi, misalnya, adalah fenomena formalisasi Islam dan islamisasi perbuatan. Menurut Abdurrahman Wahid, sebagaimana diungkapkan Mujamil Qomar, kecenderungan formalisasi Islam dalam kehidupan masyarakat dan islamisasi perbuatan dalam bentuk manifestasi simbolik ini jelas tidak menguntungkan karena hanya akan menimbulkan kekeringan substansi. Misalnya, dengan munculnya kelompok intelektual yang serba mau memformalkan Islam, dikhawatirkan Islam menjadi kehilangan relevansi. Padahal, islamisasi itu pada umumnya barulah pada arabisasi budaya, yaitu semakin banyaknya dipakai terminologi Arab yang berasal dari nash. Sementara itu, arabisasi tersebut mengandung bahaya. ${ }^{19}$

Dengan pandangan semacam ini, tidak heran apabila Gus Dur dalam konteks sejarah Indonesia adalah salah satu orang yang gencar dan keras mengkritik ICMI. Dia khawatir apabila kelompok ICMI berhasil menjadikan ICMI sebagai kekuatan politik independen, maka akan menjadi pukulan berat buat

files/ebook/Merayakan \%20Kebebasan\%20Beragama\%20DP.pdf, diakses tanggal 6 Maret 2012.

${ }^{18}$ Nurcholish Madjid, Islam Agama Kemanusiaan: Membangun Tradisi dan Visi Baru Islam Indonesia, (Jakarta: Paramadina, 2010), hlm. 20-21.

${ }^{19}$ Mujamil Qomar, op. cit., hlm. 175. 
Islam dan fatal bagi demokrasi Indonesia. Oleh karena itu, Gus Dur adalah orang yang kurang menghendaki penghadiran politik formal bagi Islam, akan tetapi lebih menghendaki agar Islam dijadikan lebih sebagai landasan nilai-nilai etik bagi kehidupan masyarakat modern. Dia senang menerima kenyataan bahwa Indonesia merupakan masyarakat multi-etnik dan multi-agama, dan mengakui hak-hak minoritas untuk mendapatkan perlindungan. Dia memandang, misalnya, retorika anti-Kristen kaum modernis dan para da'i di desa-desa yang sering menyalahkan kelompok Kristen merupakan kenyataan lemahnya kepemimpinan dalam Islam. ${ }^{20}$

Dus Dur mengatakan, bahwa proses demokratisasi kehiduapn politik dan kehidupan pemerintahan, sebenarnya memerlukan penanganan melalui rangkaian kegiatan sangat kompleks, baik oleh meraka yang berada di lingkungan pemerintahan maupun di luarnya. Adalah tidak bijaksana untuk mementingkan pandangan sekterian yang hanya mengutamakan kebenaran pihak sendiri belaka, dengan membahayakan proses integras nasional. Akibatnya adalah keretakan yang mungkin tidak akan dapat dijembatani lagi, misalnya, antara "golongan Islam” dan golongan-golongan lain di luarnya. ${ }^{21}$ Dalam hal ini, kasus ICMI bagi Gus Dur dapat dijadikan contoh.

Oleh karena itu, menurut Gus Dur, gerakan intelektual Islam dan kontribusinya dalam konteks perkembangan Islam di Indonesia harus ditempatkan pada pengertian strategis. Mendorong masuknya orang Islam dalam posisi strategis kenegaraan sebenarnya tidaklah strategis. Ini dapat disamakan dengan teknokrat yang berbondong-bondong lewat Bappenas. Mereka tidak mendobrak apa pun dan dengan demikian sama sekali tidak strategis. Sebagai suatu kelompok memang strategis, tetapi tidak untuk bangsa. Sebaliknya, akan sangat bagus jikalau kaum intelektual Islam mengambil sikap integratif, memasukkan diri pada

${ }^{20}$ Saiful Muzani, op. cit., hlm. 230-231.

${ }^{21}$ Abdurrahman Wahid, Prisma Pemikiran Gus Dur, (Yogyakarta: LKiS, 2010), hlm. 165. 
mainstreams kehidupan bangsa yang memperjuangkan demokrasi serta tatanan yang lebih adil di kemudian hari. ${ }^{22}$

Bagi Gus Dur, ketika dia membaca, menguasai, menerapkan al-Qur’an, hadis, dan kitab-kitab kuning tidak dikhususkan bagi orang Islam. Demikian pula, dia bersedia memakai yang mana pun asal benar dan cocok dengan hati nurani. Dia tidak mempedulikan apakah kutipan dari Injil atau Bhagawal Gita, jikalau itu benar maka menerimanya. Dalam masalah bangsa, ayat Al-Qur'an, menurut Gus Dur, semestinya dipakai secara fungsional, bukannya untuk diyakini secara teologis. Keyakinan teologis dipakai dalam persoalan mendasar, sedangkan aplikasinya adalah soal penafsiran. Berbicara penafsiran berarti bukan lagi masalah teologis, melainkan sudah menjadi masalah pemikiran. ${ }^{23}$

Dengan pandangan semacam ini, rasanya menjadi penting bagi umat Islam Indonesia untuk lebih memasyarakatkan penghayatan Islam yang kosmopolit. Sebagai negara-bangsa yang majemuk dari segi etnis dan agama, mungkin Indonesia perlu belajar dan meniru Inggris. Jika kaum muslim Inggris yang jumlahnya sangat minoritas masih dihargai dan dihormati hak asasinya, umat Islam Indonesia pun seharusnya belajar untuk menghormati dan menghargai hak asasi pemeluk agama lain yang (mungkin) minoritas di Indonesia. Tidak boleh ada teror atau penghakiman terhadap pemeluk agama lain. ${ }^{24}$

Sikap sebagaimana disinggung adalah sangat penting, karena bangsa Indonesia sudah mempunyai modus vevendi (kesepakatan luhur) untuk hidup bersatu dalam kebhinekaan dengan ikatan Pancasila. Modus vevendi itu menuntut masyarakat bangsa ini saling toleran dan beradab terhadap pemeluk agama lain tanpa melihat besar kecil jumlah pemeluk, karena persoalan keyakinan terhadap agama secara universal merupakan hak yang paling asasi. Secara sederhana Islam kosmopolitan dimaksudkan bahwa Islam itu harus bermanfaat bagi umat manusia, ramah, tidak ditakuti, dan menimbulkan kadamaian bagi setiap orang. Yang diperjuangkan dalam Islam kosmopolitan adalah nilai-nilai universal yang inklusif

${ }^{22}$ Ibid., hlm. 197-202.

${ }^{23}$ Ibid., hlm. 204.

${ }^{24}$ Mahfud MD, Gus Dur: Islam, Politik, dan Kebangsaan, (Yogyakarta: LKiS, 2010), hlm. 77. 
yang pasti diterima oleh setiap orang. Perjuangannya tdak menghendaki formalisasi atau simbol-simbol ekslusif yang memberi kesan mengecilkan kelompok lain, tetapi menekankan diri pada nilai dasarnya yang universal, seperti menegakkan keadilan dan hukum dalam bentuk perlawanan terhadap penguasa yang korup dan zalim, pembelaan terhadap kaum lemah, dan sebagainya. ${ }^{25}$

Gus Dur sendiri dianggap merupakan figur yang memiliki kelebihan yang sangat fleksibel dalam membangun hubungan sosial dengan tokoh-tokoh non muslim. Gus Dur sangat bersahabat dengan banyak kalangan pastor dan pendeta, termasuk dengan tokoh-tokoh non muslim lainnya seperti dari kalangan Budha, Hindu, dan Kong Hu Cu (Cina). ${ }^{26}$ Dalam pandangan Gus Dur, Departemen Agama sebagai aparat negara adalah milik semua dan melayani semua. Di mata Gus Dur, setiap dan semua umat beragama mempunyai kebebasan untuk bereksistensi dan berekspresi sesuai dengan keyakinannya. ${ }^{27}$

Memang Gus Dur mendambakan kehidupan agama yang ramah. Masingmasing umat beragama tentu meyakini kebenaran agama yang mereka anut, sebab hanya dalam keyakinan yang tulus itulah terletak keberagamaan yang hakiki, tetapi pada saat yang sama mereka juga seyogianya menghormati orang lain untuk meyakini kebenaran agama yang mereka anut dan melaksanakannya secara bebas. Suasana saling menghormati itu juga tentu saja berlaku di antara semua pemeluk agama apa pun. Sebab, dalam masing-masing umat satu agama terbuka perbedaan bahkan pertentangan keyakinan, tetapi mereka tidak perlu menjegal orang lain. Gus Dur agaknya ingin melihat bahwa dalam taman Indonesia aneka macam bunga biarlah tumbuh secara wajar tanpa dihalang-halangi dan juga tidak dipaksapaksa. $^{28}$

${ }^{25}$ Ibid., hlm. 78.

${ }^{26}$ Laode Ida, NU Muda Kaum Progresif dan Sekulerisme, (Jakarta: Erlangga, 2004), hlm. 138

${ }^{27}$ Djohan Effendi, "Kehidupan Umat Beragama dalam Cita-Cita Gus Dur”, dalam Irwan Suhanda, Gus Dur Santri Par Exellence: Teladan Sang Guru Bangsa, (Jakarta: Kompas, 2010), hlm. 128.

${ }^{28}$ Ibid., hlm. 129. 
Tampaknya, sikap inklusif adalah landasan yang ingin disodorkan Gus Dur dalam hubungan antar manusia. Kaitannya dengan keyakinan beragama, secara substansial, menurut Nurkholish,

"paham keberagamaan inklusif mengandung arti bahwa seluruh kebenaran agama lain ada juga dalam agama kita. Pada dasarnya seluruh agama adalah sama dan satu. Dalam al-Qur'an, misalnya, diilustrasikan bahwa semua Nabi dan Rasul itu adalah muslim (orang yang pasrah kepada Allah). Semua agama para Nabi dan Rasul itu adalah Islam, dalam artinya yang asli. Sementara Islam par exellance adalah bentuk terlembaga dari agama yang sama itu. Sehingga semua agama itu sebenarnya adalah satu dan sama. Perbedaannya hanyalah dalam bentuk syari'ah. Dalam bahasa keahamaan inilah yang disebut “jalan”. Setiap agama adalah “jalan” kepada Tuhan. ${ }^{29}$

\section{E. Penutup}

Adalah sebuah kenyataan bahwa Indonesia adalah bangsa yang majemuk, plural, dan beragam. Setelah Indonesia lahir, masyarakat bangsa ini semestinya menyadari bahwa mereka adalah tidak satu, banyak suku, banyak agama, dan banyak latar belakang budaya yang berbeda. Demikian pula seiring dengan perkembangan zaman dan di era globalisasi ini, jelas keragman semakin tampak. Masyarakat Indonesia, pada era ini, tidak hanya harus bisa bergaul dengan sesama bangsa Indonesia, akan tetapi juga harus dapat menerima bangsa lain sekaligus pengaruh budayanya. Pertanyaanya adalah, bagaimana masyarakat Islam khususnya menyikapi kenyataan ini? Tentu saja, jika harus memilih dari berbagai pilihan, maka sikap pluralisme (pluralism) tampaknya adalah pilihan yang tepat. Sebagaimana telah disinggung bahwa pluralisme adalah sistem nilai, sikap, institsi, dan proses yang bisa menterjemahkan realitas keragaman itu menjadi kohesi sosial yang berkelanjutan, stabilitas politik, dan pembangunan ekonomi.

Jadi, ketika ber-Islam dalam bingkai Indonesia atau bahkan dalam bingkai dunia, maka tawaran dan gagasan Gus Dur untuk berpegang pada pluralisme adalah sesuatu yang realistis. Pancasila bagi umat Islam Indonesia, menurut Gus Dur, mestinya harus dapat diterjemahkan sebagai rahmatan lil 'alamin. Pancasila sekaligus dapat dijadikan senjata untuk aksi penyikapan atas keberagaman dan

${ }^{29}$ Nurcholish Madjid, Cendikiawan dan Religiusitas Masyarakat, (Jakarta: Paramadina, 2009), hlm. 67. 
paradigma yang kritis untuk mencapai titik temu dari perbedaan yang ada. Pancasila tampak efektif, bagi umat Islam Indonesia, untuk digunakan sebagai alat penegakkan nilai-nilai Islam di bumi Indonesia ini. Nilai-nilai Islam, seperti penegakkan keadilan, persatuan, penghargaan atas hak asasi manusia, dan pemberian kebebasan inilah yang sebenarnya ingin dicapai dengan Pancasila. Pancasila adalah bahasa kesamaan, meminjam konsepnya Azyumardi Azra, untuk mencapai tujuan yang sama antar sesama komponen bangsa Indonesia dan dapat dijadikan sebagai senjata untuk menghadapi musuh bersama.

Dalam hal ini, tidak aneh apabila Gus Dur sering mengingatkan bahwa orang orang Indonesia harus berhati-hati untuk mengamati perkembangan kelompok-kelompok 'pemaksa'. Indonesia bukanlah negara Islam, karenanya hanya berpegang kepada Undang-Undang Dasar. Masyarakat Indonesia harus berani mempertahankan dengan segala cara yang sah menurut hukum UndangUndang Dasar tersebut. Kalau ada orang yang menyatakan kita melanggar ketentuan-ketentuan Islam, dengan menggunakan contoh negara lain, kita harus berani menyatakan bahwa negara kita adalah Negara Nasionalistik, bukannya Negara Islam. Kenyataan ini harus ditekankan berulang kali. Sikap ini sebagai bagian dari sikap melestarikan atau merubah kehidupan kita secara sungguhsungguh. ${ }^{30}$

\section{DAFTAR PUSTAKA}

Abdullahi Ahmed An-Na'im, Islam dan Negara Sekuler: Menegosiasikan Masa Depan Syariah, terj. Sri Murniati, (Bandung: Mizan, 2007).

Abdurrahman Wahid, "Nahdatul Ulama dan Islam di Indonesia dewasa Ini”, dalam Taufif Abdullah dan Sharon Siddique, Tradisi dan Kebangkitan Islam di Indonesia, (Jakarta: LP3ES, 1988).

"Bercermin Dari Para Pemimpin”, dalam Abdul Mu’nim D.Z. (ed.), Islam di Tengah ArusTransisi, (Jakarta: Kompas, 2000).

30 Abdurrahman Wahid , "Cinta Konseptual dan Cinta Kongkret”, http://www.gusdur.net/indonesia/index.php?option=com_content\&task=view\&id $=2349 \&$ Itemid $=62$. 
, "Musuh dalam Selimut", Pengantar Editor, dalam Abdurrahman Wahid (ed.), Ilusi Negara Islam: Ekspansi Gerakan Islam Transnasional di Indonesia, (Jakarta: Desantra Utama Media, 2009). , Prisma Pemikiran Gus Dur, (Yogyakarta: LKiS, 2010).

Aden Wijdan SZ. dkk, Pemikiran dan Peradaban Islam, (Yogyakarta: Safiria Insania Press).

Ali Maschan Moesa, NU Agama dan Demokrasi:Komitmen Muslim Tradisional Terhadap Nilai-Nilai Kebangsaan, (Surabaya: Putra Pelajar, 2002).

Amin Abdullah, M., Studi Agama: Normativitas atau Historisitas?, (Yogyakarta: Pustaka Pelajar, 2002).

Andreas A. Yewangoe, "Regulasi Toleransi dan Pluralisme Agama di Indonesia”, http://abad-demokrasi.com/sites/default/files/ebook/Merayakan\%

20Kebebasan \%20Beragama\%20DP .pdf, diakses tanggal 6 Maret 2012.

Azyumardi Azra, “Toreransi Agama dalam Masyarakat Majemuk: Perspektif Muslim Indonesia”, http://abaddemokrasi.com/sites/default/files/ebook/ Merayakan \%20 Kebebasan\%20 Beragama\%20DP.pdf, diakses tanggal 6 Maret 2012.

Djohan Effendi, “Kehidupan Umat Beragama dalam Cita-Cita Gus Dur”, dalam Irwan Suhanda, Gus Dur Santri Par Exellence: Teladan Sang Guru Bangsa, (Jakarta: Kompas, 2010).

Greg Barton, "Memahami Abdurrahman Wahid”, dalam Abdurrahman Wahid, Prisma Pemikiran Gus Dur, (Yogyakarta: LKiS, 2010).

Greg Barton, Biografi Gus Dur, terj. Lie Hua, (Yogyakarta: LKiS, 2010).

Mahfud MD, Gus Dur: Islam, Politik, dan Kebangsaan, (Yogyakarta: LKiS, 2010).

Nurcholish Madjid, Islam Agama Kemanusiaan: Membangun Tradisi dan Visi Baru Islam Indonesia, (Jakarta: Paramadina, 2010).

Mujamil Qomar, NU Liberal: Dari Tradisionalisme Ahlusunnah ke Universalisme Islam, (Bandung: Mizan, 2002).

Saiful Muzani, "Mitos Politik dan Aspirasi Politik ICMI Modernis”, Book Review, Adam Schwarz, "Islam: Coming in from the Cold?, dalam bukunya, A Nation in Waiting, Indonesia in the 1990's, (Sydney: Allan and Unwin, 1994), Studia Islamika, Volume 2, Number 1, 1995. 